\title{
Article \\ Systematic Search for Novel Circulating Biomarkers Associated with Extracellular Vesicles in Alzheimer's Disease: Combining Literature Screening and Database Mining Approaches
}

\author{
David Vogrinc ${ }^{1}$, Katja Goričar ${ }^{1}\left(\mathbb{D}\right.$, Tanja Kunej ${ }^{2, *(\mathbb{D})}$ and Vita Dolžan ${ }^{1, * \mathbb{C}}$ \\ 1 Pharmacogenetics Laboratory, Institute of Biochemistry and Molecular Genetics, Faculty of Medicine, \\ University of Ljubljana, 1000 Ljubljana, Slovenia; david.vogrinc@mf.uni-lj.si (D.V.); \\ katja.goricar@mf.uni-lj.si (K.G.) \\ 2 Department of Animal Science, Biotechnical Faculty, University of Ljubljana, 1000 Ljubljana, Slovenia \\ * Correspondence: tanja.kunej@bf.uni-lj.si (T.K.); vita.dolzan@mf.uni-lj.si (V.D.)
}

\section{check for} updates

Citation: Vogrinc, D.; Goričar, K. Kunej, T.; Dolžan, V. Systematic Search for Novel Circulating Biomarkers Associated with Extracellular Vesicles in Alzheimer's Disease: Combining Literature Screening and Database Mining Approaches. J. Pers. Med. 2021, 11, 946. https://doi.org/10.3390/ jpm11100946

Academic Editor: Valentina Bessi

Received: 4 August 2021

Accepted: 19 September 2021

Published: 23 September 2021

Publisher's Note: MDPI stays neutral with regard to jurisdictional claims in published maps and institutional affiliations.

Copyright: (c) 2021 by the authors. Licensee MDPI, Basel, Switzerland. This article is an open access article distributed under the terms and conditions of the Creative Commons Attribution (CC BY) license (https:// creativecommons.org/licenses/by/ $4.0 /)$.

\begin{abstract}
RNAs play an important role in neurodegenerative diseases. Many miRNA-target gene interactions (MTI) have been experimentally confirmed and associated with Alzheimer's disease (AD). miRNAs may also be contained within extracellular vesicles (EVs), mediators of cellular communication and a potential source of circulating biomarkers in body fluids. Therefore, EV-associated miRNAs (EV-miRNAs) in peripheral blood could support earlier and less invasive AD diagnostics. We aimed to prioritize EV-related miRNA with AD-related genes and to identify the most promising candidates for novel AD biomarkers. A list of unique EV-miRNAs from the literature was combined with a known set of AD risk genes and enriched for MTI. Additionally, miRNAs associated with the AD phenotype were combined with all known target genes in MTI enrichment. Expression in different sample types was analyzed to identify AD-associated miRNAs with the greatest potential as AD circulating biomarkers. Four common MTI were observed between EV-miRNAs and AD-associated miRNAs: hsa-miR-375-APH1B, hsa-miR-107-CDC42SE2, hsa-miR375-CELF2, and hsa-miR-107-IL6. An additional 61 out of 169 unique miRNAs (36.1\%) and seven out of 84 unique MTI (8.3\%), observed in the body fluids of AD patients, were proposed as very strong AD-circulating biomarker candidates. Our analysis summarized several potential novel AD biomarkers, but further studies are needed to evaluate their potential in clinical practice.
\end{abstract}

Keywords: Alzheimer's disease; biomarker; miRNA; extracellular vesicles

\section{Introduction}

Progressive neurodegeneration is a feature of various age-related brain disorders, including Alzheimer's disease (AD). AD is the leading cause of dementia, and the increase in lifespan is making it one of the most important global health issues. Mild cognitive impairment (MCI) is the main feature of the pre-dementia stage of the disease, while severe memory and learning dysfunction can be observed during disease progression [1]. Typical $\mathrm{AD}$ cases are also known as late-onset AD. Onset of symptoms before 65 years of age is uncommon and is regarded as early-onset AD [2]. Multiple risk factors contribute to the development of AD and the mechanisms of disease pathogenesis are still not completely understood [3].

Various genetic risk loci contribute to the development of the disease. For the most frequent form of the disease, sporadic AD, there are no common causative genes. Different studies report that rather than single genes, polygenic risk scores can be used to predict AD risk [4-6]. Numerous GWAS have identified AD risk loci [7-9]. Apart from genetic background, epigenetic mechanisms may play an important role in AD pathogenesis as well [10]. Small, non-coding RNA have been extensively studied in neurodegenerative diseases. miRNAs are involved in post-transcriptional regulation of gene expression. Upon 
binding primarily to the $3^{\prime}$ untranslated region of the messenger RNAs (mRNAs), miRNAs block the translation or lead to degradation of target mRNAs [11]. One miRNA can target multiple mRNAs, and many interactions have been associated with disease mechanisms [12]. More than 380,000 experimentally validated miRNA-target gene interactions (MTI) have been reported in H. sapiens alone [13]. Data on MTI are important as they may improve our understanding of metabolic processes and biological pathways associated with neurodegenerative changes in the brain.

Although AD diagnostic criteria are well established, lack of specificity and sensitivity in $\mathrm{AD}$ diagnoses can be observed [14]. Since there is no currently available treatment for the advanced state of the disease, early diagnostics of preclinical AD is extremely important. Detectable cerebrospinal fluid (CSF) proteins reflect cerebral accumulation of insoluble plaques and aggregation of neurofibrillary tangles (NFT), two major hallmarks of AD [15]. Decreased amyloid- $\beta\left(A \beta_{1-42}\right)$, increased total Tau (tTau), and phospho Tau (pTau) from CSF are used in clinical practice as suitable biomarkers to support AD diagnostics [16]. Measurement of CSF $A \beta_{40}, A \beta_{42}$, pTau, and tTau showed good diagnostic accuracy in discriminating $\mathrm{AD}$ patients from non-AD patients, with the $\mathrm{A} \beta_{42 / 40}$ ratio performing best [17-20]. However, accumulation of protein aggregates is common between different neurological disorders, especially in early stages of the disease [21-23]. Discrepancies in CSF biomarker measurement approaches between different clinical centers add to the variability in AD diagnostics. Hence, studies are trying to identify novel reliable ADspecific biomarkers capable of sensing initial neurodegenerative changes in the brain. Circulating miRNAs and target genes bear great potential as AD-related biomarkers and could provide valuable insight into the cellular mechanisms of AD pathology [24].

Extracellular vesicles (EVs) are being extensively studied as source of novel ADrelated biomarkers. EVs play a key role in intercellular communication as they harbor proteins, RNAs, and lipids with important functions in the central nervous system [25]. Whether EVs contribute to pathophysiological changes observed in AD is still subjected to discussion. Both amyloid and tau pathologies have been associated with neuronal-derived EVs. Release of $A \beta$ from cells in vitro and $A \beta$-induced synaptic disruption in vivo was associated with EVs [26-28]. AD-associated tau phosphoforms have been found in EVs isolated from $\mathrm{AD}$ patients [29]. Furthermore, brain-derived EVs are able to cross the blood-brain barrier, suggesting they could have potential as circulating biomarkers in body fluids [30]. EV cargo has been extensively studied in neurodegenerative disorders. Differentially expressed EVs enriched mRNAs and miRNAs in blood serum and CSF were reported (reviewed in [31]). Several case-control studies identified miRNAs enriched in EVs (EV-miRNAs) isolated from body fluids in AD patients [24,32-35]. These findings suggest EV-miRNAs may have an important role in complex regulatory networks of AD. Better understanding of miRNA function in AD pathogenesis could eventually contribute to the development of novel earlier and less invasive diagnostic approaches.

Therefore, the aim of our study was to prioritize EV-related miRNA biomarkers of AD based on interactions with known AD-related genes. Additionally, we wanted to identify the most promising circulating miRNAs and their MTI that could serve as biomarkers in AD.

\section{Methods}

Two different approaches, based on literature screening or database mining, were used in search for miRNA-target interactions in Alzheimer's disease.

In the first approach, we tried to identify MTI with known AD-related genes for miRNAs enriched in EVs in AD. A PubMed search for original articles published from November 2014 until the end of February 2021 was performed using keywords "Alzheimer's disease, extracellular vesicle, miRNA". A list of unique EV-miRNAs was combined with a known set of genes previously associated with AD risk and biomarker levels in GWAS studies [36]. Enrichment for MTI was performed by using miRTarBase (http: // mirtarbase.cuhk.edu.cn/php/index.php, accessed on 25 March 2021) (Figure 1a). In 
miRTarBase, experimentally validated MTI are reported according to different confirmation methods [13].

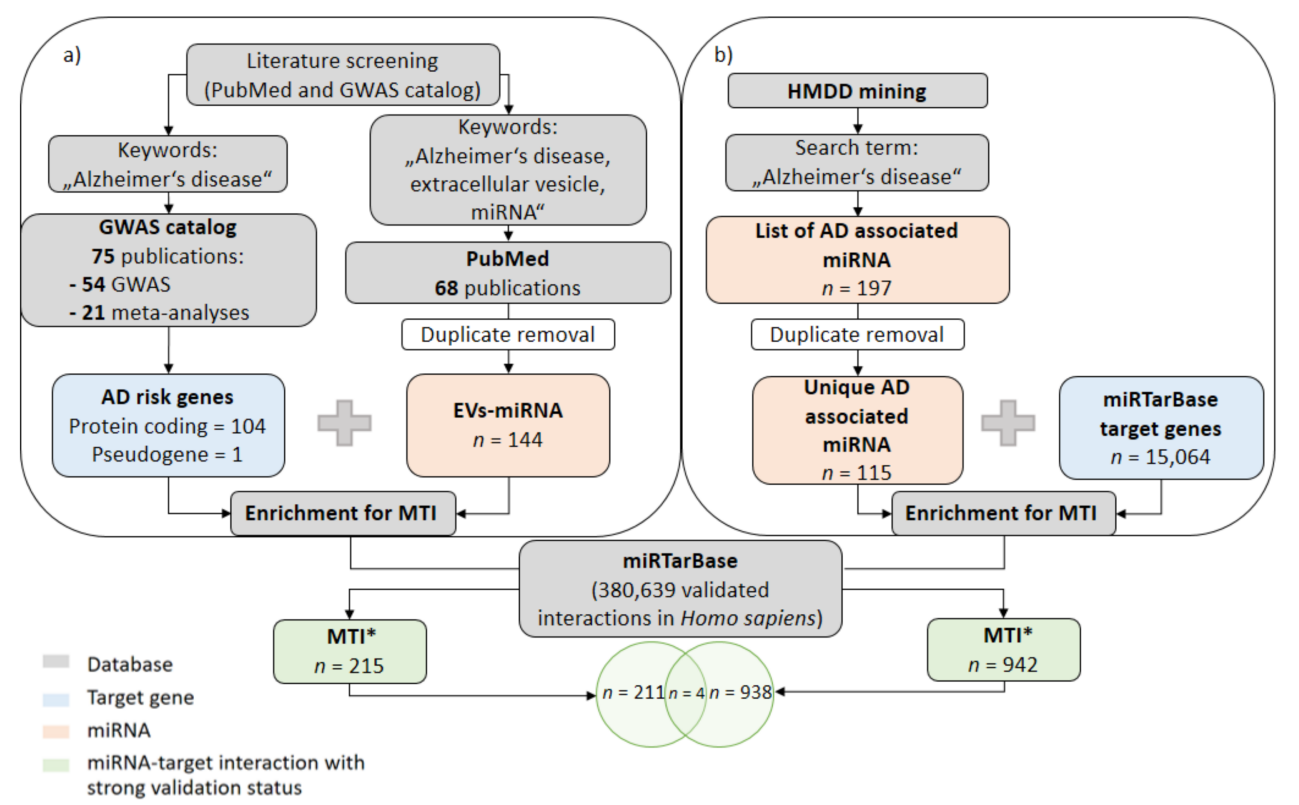

Figure 1. Integration of literature screening and database mining for AD-related miRNAs and target gene evaluation and prioritization of MTI: (a) Previously published work on AD risk genes was combined with a list of miRNAs associated with extracellular vesicles obtained from literature search. miRNA-target interactions on various phenotypes and diseases were extracted from miRTarBase. (b) Apart from that, HMDD mining resulted in list of AD-associated miRNAs that were combined with the complete list of genes in miRTarBase for evaluation of miRNA-target interactions. $\mathrm{AD}=$ Alzheimer's disease; EVs = extracellular vesicles; HMDD = Human microRNA Disease Database; $\mathrm{MTI}=$ miRNA-target interaction.

In the second approach, we tried to identify MTI for all miRNAs associated with AD reported in the Human microRNA Disease Database-HMDD (https:/ / www.cuilab.cn/ hmdd, accessed on 25 March 2021). The HMDD annotates miRNAs associated with a specific disease phenotype [12]. After duplicate removal, a list of all unique AD-associated miRNAs was combined with all known target genes in miRTarBase for MTI enrichment (Figure 1b).

Furthermore, a list of all AD-associated miRNAs from HMDD was prioritized according to the level of evidence. In a search for miRNAs with the greatest potential as AD circulating biomarkers, their expression in different sample types was reviewed (Figure 2). As reported in the original literature, candidate miRNAs were observed in biological samples of $\mathrm{AD}$ patients (very strong candidates), AD animal or cell culture models (strong candidates), non-AD animal or cell culture models (possible candidates), and in silico predictions (potential candidates). Original papers were screened for reported MTI. Overlap between different categories was visualized with a Venn diagram using the Venny tool [37]. 


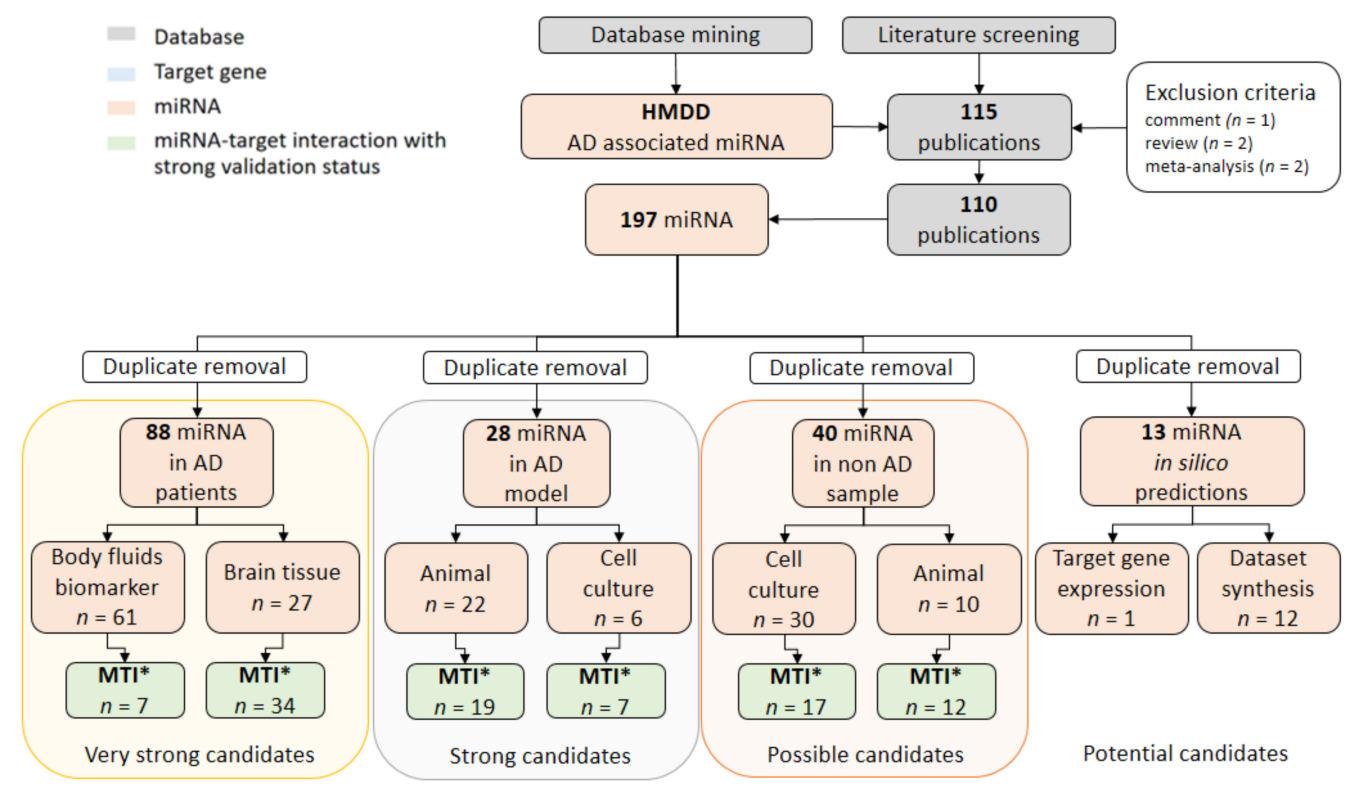

Figure 2. Data extraction of AD-associated miRNAs from HMDD and manual literature curation of experimentally validated MTI. Database mining resulted in a list of publications, investigating the role of derived miRNAs that were manually screened for their abundance in different sample types. miRNAs were curated as very strong candidates (association observed in a sample of AD patients), strong candidates (association observed in AD cell or animal models), and possible candidates (association observed in non-AD cell or animal models). In silico predictions were also highlighted as potential $\mathrm{AD}$-associated candidates, suggesting further research. $\mathrm{AD}=$ Alzheimer's disease; HMDD = Human microRNA Disease Database; MTI $^{*}=$ miRNA-target interaction, extraction from previously published literature.

\section{Results}

Based on the literature search, 144 unique EV-miRNAs were found (Figure 1a). In the HMDD, 115 unique AD-associated miRNAs were reported (Figure 1b). Only six miRNAs were common between both datasets: hsa-miR-29c, hsa-miR-136-3p, hsa-miR-16-2, hsa-miR132-5, hsa-miR-331-5p, and hsa-miR-485-5p. Combining EV-miRNAs from 68 publications with a list of 105 AD-related genes resulted in 215 specific MTI. HMDD screening resulted in 942 MTI. An overlap between the two approaches showed four common MTI, hsa-miR375-APH1B, hsa-miR-107-CDC42SE2, hsa-miR-375-CELF2, and hsa-miR-107-IL6, with the greatest potential as EV-miRNA circulating biomarkers (Table 1).

Table 1. Common experimentally confirmed MTI identified by both literature screening and database mining approaches.

\begin{tabular}{cccc}
\hline miRNA & Target Gene & Method & PubMed ID (Reference) \\
\hline hsa-miR-375 & APH1B & Microarray & 20215506 [38] \\
\hline hsa-miR-375 & CELF2 & Microarray & 20215506 [38] \\
\hline hsa-miR-107 & CDC42SE2 & PAR-CLIP ${ }^{1}$ & 21572407 [39] \\
\hline hsa-miR-107 & IL6 & $\begin{array}{l}\text { Luciferase reporter assay, } \\
\text { RT-qPCR }\end{array}$ & , Western blot \\
\hline
\end{tabular}

${ }^{1}$ PAR-CLIP: photoactivatable ribonucleoside-enhanced crosslinking and immunoprecipitation; ${ }^{2}$ RT-qPCR: reverse transcription quantitative polymerase chain reaction.

After duplicate removal, prioritization of 169 unique HMDD miRNAs associated with $\mathrm{AD}$ in different sample types resulted in 88 very strong AD biomarker candidates (Figure 2, Table S1). While 61 (36.1\%) of them served as body fluids biomarker, $27(16 \%)$ were differentially expressed in brain tissue. Only 14 miRNAs were observed both in 
body fluids and brain samples. A total of 28 miRNAs regarded as strong candidates were observed in animal (22) or cell culture (6) models of AD. Only four miRNAs were common between both models. Expression of another 40 possible candidates was observed in other, non-AD cell culture (30) or animal models (10), with an overlap of four miRNAs. On the other hand, 13 miRNAs were linked to AD by in silico predictions. The overlap between different prioritization categories can be seen in a Venn diagram in Figure 3. Only one miRNA, hsa-mir-34a, was observed in all four categories.

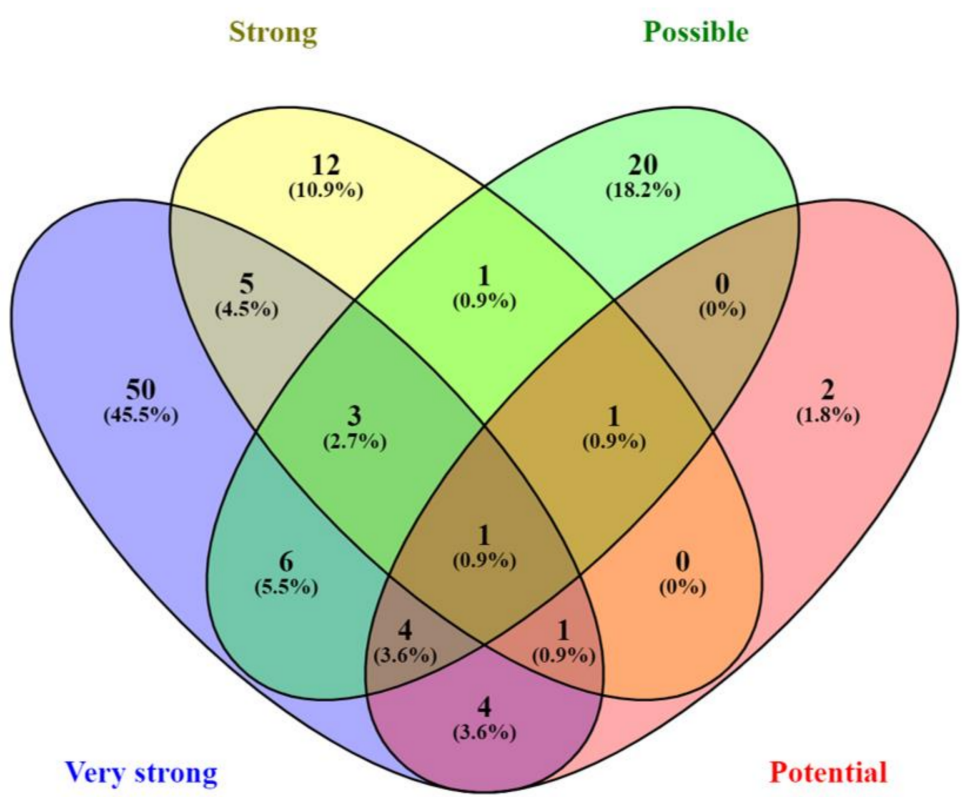

Figure 3. Overlap of common identified miRNAs between different candidate categories, according to the level of evidence.

For all HMDD-identified miRNAs, we proposed key AD-related MTI by screening original papers (Figure 2, Table S1). We identified seven (8.3\%) experimentally validated MTI from 84 unique MTI in the body fluids of AD patients, while $34(40.5 \%)$ MTI were confirmed in AD brain tissue samples. Another 19 MTI were found in AD animal models and seven were associated with AD cell cultures. In non-AD samples, 17 MTI were found in cell cultures and 12 in animal models. Seven MTI prioritized to have the greatest potential as novel AD biomarkers are highlighted in Table 2.

Table 2. Experimentally confirmed MTI prioritized as very strong AD-related candidates.

\begin{tabular}{|c|c|c|c|}
\hline miRNA & Target Gene & Method & PubMed ID (Reference) \\
\hline hsa-miR-193b & $A P P$ & Luciferase reporter assay, RT-qPCR ${ }^{1}$, Western blot & $25119742[41]$ \\
\hline hsa-miR-29c & BACE1 & Luciferase reporter assay, RT-qPCR ${ }^{1}$, Western blot & 25955795 [42] \\
\hline hsa-miR-613 & $B D N F$ & EGFP reporter assay, RT-qPCR ${ }^{1}$, Western blot & $27545218[43]$ \\
\hline hsa-miR-29c & DNMT3 & Luciferase reporter assay, RT-qPCR ${ }^{1}$, Western blot & $25815896[44]$ \\
\hline hsa-miR-206 & IGF1 & Luciferase reporter assay, RT-qPCR ${ }^{1}$, Western blot & 27277332 [45] \\
\hline hsa-miR-128 & PPARG & Luciferase reporter assay, RT-qPCR ${ }^{1}$, Western blot & $30328325[46]$ \\
\hline hsa-miR-146a & TLR2 & Luciferase reporter assay, RT-qPCR ${ }^{1}$, Western blot & $26095531[47]$ \\
\hline
\end{tabular}




\section{Discussion}

miRNAs and their target genes are extensively studied as potential AD circulating biomarkers. We prioritized EV-related miRNA biomarkers interacting with known ADrelated genes and identified the most promising circulating miRNAs and their MTI that could serve as biomarkers for AD.

Four EV-associated MTI (hsa-miR-375-APH1B, hsa-miR-107-CDC42SE2, hsa-miR-375CELF2, and hsa-miR-107-IL6) were identified by our combined literature screening and database mining approaches. Using the HMDD, seven MTI (hsa-miR-193b-APP, hsa-miR29c-BACE1, hsa-miR-613-BDNF, hsa-miR-29c-DNMT3, hsa-miR-206-IGF1, hsa-miR-128PPARG, and hsa-miR-146a-TLR2) were observed in the body fluids of AD patients.

Two miRNAs were prioritized as the most promising EV-related biomarkers based on interactions with known AD-related genes: hsa-miR-375 and hsa-miR-107. Microarray analysis identified two EV-related hsa-miR-375 target genes, APH1B and CELF2. APH1B encodes for anterior pharynx defective- 1 protein, a crucial part of the $\gamma$-secretase complex. Together with PS1/PS2 and PEN2, it is involved in cleavage of amyloid-precursor proteins (APP) in the amyloid cascade [48]. Depletion of Aph1b in mice leads to a progressive neurodegenerative phenotype and indicates $A P H 1 B$ as a potential AD treatment target [49]. APP, PS1, and PS2, encoded by APP, PSEN1, and PSEN2, are common causative genes for a familial, early-onset type of $\mathrm{AD}$ [2]. Therefore, $A P H 1 B$ was also proposed as an AD-risk locus. APH1B missense variant rs117618017 was recently identified as a high-confidence $\mathrm{AD}$ risk variant $[8,50]$. CELF2 is an RNA-binding protein implicated in alternative splicing of TREM2 [51]. The effect of TREM2 in neuronal inflammation, present also in AD, has been extensively studied. TREM2 is a key player in the microglial response to increased amyloid burden [52]. Multiple genetics studies revealed TREM2 as an important AD risk locus $[9,53,54]$. Furthermore, CELF2 rs201119 was associated with increased AD risk [55]. Interaction of hsa-miR-375 with both APH1B and CELF2 was experimentally confirmed in a gastric carcinoma sample [38]. The importance of hsa-miR-375 has also been studied in neurological disorders. The effect of hsa-miR-375 in promoting oxidative stress accompanying AD has been proposed [56]. Furthermore, hsa-miR-375 was differentially expressed in CSF and was highlighted as an AD biomarker [24].

Two EV-related hsa-miR-107 target genes, CDC42SE2 and IL6, were confirmed using different experimental approaches. CDC42SE2 is a potential actin cytoskeleton modulator acting downstream of CDC42 [57]. The importance of actin in AD pathology and involvement in synaptotoxicity has previously been established [58,59]. CDC42SE2 rs382216 was associated with decreased AD risk in a GWAS study [60]. Cytokines are generally recognized as important mediators of inflammation. Multiple lines of evidence link IL6 with neurodegeneration. Elevated IL6 levels have been observed in AD brain tissue [61,62]. IL6 is also important in neuronal cell growth and differentiation [63]. Recently, rs1800796 in IL6 has been associated with increased AD risk in a meta-analysis [64]. Furthermore, multiple polymorphisms in gene coding for IL6 receptors (IL6R) were found in AD GWAS studies $[65,66]$. Thus, the importance of both IL6 and IL6R in the genetic predisposition of disease imply the importance of cytokines in the development of AD. Experimental validation of hsa-miR-107 interactions with CDC42SE2 and IL6 were already reported [39,40]. In an AD cell model, a decrease in hsa-miR-107 level was observed, suggesting its function in disease progression [67]. The potential of hsa-miR-107 as an AD circulating biomarker was proposed, since lower expression in blood plasma was observed in AD patients [68].

Six miRNAs were prioritized as the most promising circulating biomarkers based on HMDD data. Seven MTI prioritized in the database mining approach were confirmed with reliable methods-reporter assay, RT-qPCR, and Western blot. One MTI, hsa-miR-193-APP, was also observed in EVs [41]. 
Multiple miRNA target genes were associated with metabolic processes and regulation of gene expression. The interaction of exosomal hsa-miR-193b with APP was experimentally confirmed in an AD mouse model and a sample of AD patients [41]. Later on, the potential of hsa-miR-193b as an early diagnostic circulating biomarker was confirmed $[69,70]$. APP encodes for amyloid precursor proteins and is the initial part of the amyloidogenic pathway [15]. APP is involved in synapse formation and stability and thus highly enriched in brain tissue [71]. Another gene linked to synaptic function is BACE1. BACE1 is a secretase, mediating a two-step generation of A $\beta$ through APP cleavage [72]. Since it has been discovered in CSF, the potential of BACE1 as an AD biomarker was extensively studied [73-77]. BACE1 polymorphisms were also associated with $\mathrm{AD}[78,79]$. Interaction of hsa-miR-29c with both BACE1 and DNMT3 was experimentally confirmed in CSF or blood samples [42,44]. De novo methyltransferase DNMT3 established methylation patterns on DNA and had an important role in genome imprinting [80]. Potential use of hsa-miR-29c as an AD circulating biomarker was further confirmed using RNA deep sequencing [81]. Brain-derived neurotrophic factor (BDNF) is another important protein involved in AD pathology. BDNF mediates survival and differentiation of neurons [82]. In $\mathrm{AD}$ brains, decreased BDNF levels have been reported [83]. In addition, BDNF decreases in serum during the initial stages of $A D$, suggesting $B D N F$ has an important function in early synaptic dysfunctions [84]. Furthermore, BDNF polymorphisms have been associated with $\mathrm{AD}[85,86]$. hsa-miR-613 as an interacting partner of $B D N F$ was detected in the serum and CSF of AD patients and AD mouse models [43].

One miRNA target gene was involved in immune response, an important companion of AD. The function of hsa-miR-146a in AD has been extensively studied. Recently, hsa-miR-146a upregulation was observed in postmortem AD brain tissue [87]. The effect of hsa-miR-146a as a switch for reduced proinflammatory microglial phenotypes was proposed [88]. Increased AD risk effect of rs2910164 minor allele in the miR-146a coding region was reported $[47,89]$. Multiple studies proposed hsa-miR-146a as an AD circulating biomarker [81,90,91]. An experimental interaction of hsa-miR-146a with TLR2 was reported [47]. Toll-like receptor 2, encoded by TLR2, is a key component in the innate immune system. TLR2 are one of the most studied pattern recognition receptors that recognize pathogens and initiate the cascade of host defense mechanisms [92]. The activation of TLR2 induces neurodegeneration and cognitive deficit in AD murine models [93,94]. Further evidence elucidated the role of immune system in AD development, including TLR2 polymorphisms associated with AD in Asian populations $[95,96]$.

Another two target genes were associated with glucose metabolism. PPARG is a receptor involved in lipid and glucose metabolism [97]. Interaction of a neuroprotective agent with PPARG has been discussed, suggesting the importance of PPARG in A $\beta$ formation during inflammation [98]. In addition, the effect of PPARG polymorphisms on AD risk and age of onset was evaluated $[99,100]$. Upregulation of hsa-miR-128 lead to downregulation of PPARG in clinical AD samples and AD cell models [46]. Furthermore, the importance of hsa-miR-128 in AD pathology suggests impaired amyloid clearance associated with hsamiR-128 upregulation and reduced $A \beta$ production in miR-128 knock-out mice [101,102]. Recently, hsa-miR-128 was proposed as potential AD circulating biomarker [103]. Insulin growth factor-1 (IGF1) is a hormonal regulator of insulin resistance in diabetes. The effects of IGF1 on cell survival, apoptosis, and stimulation of neurogenesis in the hippocampus can predict neurodegeneration, encompassing AD [104]. Decreases in serum levels of IGF1 have been linked to AD [105]. The effect of diabetes as an AD risk factor has also been extensively studied. IGF1 levels were associated with cognitive decline in diabetic patients [106]. In terms of genetics, only one IGF1 polymorphism was associated with AD risk in the Chinese Han population [107]. Upregulation of hsa-miR-206 in AD blood samples was linked to IGF1 and AD-related inflammation [45]. Further studies confirmed the potential of hsa-miR-206 as a circulating AD biomarker [69,108,109]. Furthermore, hsa-miR-206 was proposed as a novel AD pharmacological target [110]. 
In a search for novel, reliable AD circulating biomarkers from publicly available databases, we determined the most promising AD-related miRNA candidates and their MTI using two different approaches. The overlap between two comprehensive miRNA datasets resulted in only a few common MTI. However, not all specific MTI were confirmed in an AD sample. Contrary to our expectation, the EV-associated miRNA list did not overlap with the extensive list of miRNAs linked to AD phenotype. To better understand the function of enriched MTI in AD, a manual curation according to previously published evidence was performed. We observed no overlap between MTI obtained from EV-miRNA enrichment and very strong candidate MTI from manual prioritization. However, not all studies confirmed that miRNAs identified in our study can serve as suitable biomarkers for AD. For example, even though they were often associated with $\mathrm{AD}$, no significant differences in expression levels of miR-146a, miR-107, miR-375, and miR-29c in CSF or blood samples were observed in some studies [111-117]. In addition, statistical analysis of candidate biomarkers could help in prioritization of miRNAs as AD biomarkers. Further studies are therefore needed to confirm the role of these miRNAs and their MTI in AD.

Although hsa-mir-34a, hsa-miR-136-3p, hsa-miR-16-2, hsa-miR-132-5, hsa-miR-331-5p, and hsa-miR-485-5p were proposed as AD biomarkers using both approaches, no significant MTI were identified. The majority of included studies reported miRNA expression as upor downregulated, normalized to other common miRNAs. Determination of cut-off values for miRNA expression is challenging and rarely reported [70,118]. In the design of future studies, this should also be taken into account. Additionally, in body fluids, miRNAs are abundant as cell free or enriched in EVs. As the potential of neuronal-derived EVs in peripheral blood has been extensively studied, we focused on EVs as a promising source of miRNAs. EV-enriched miRNAs set can differ from total miRNAs in a sample, which was also highlighted by our analysis. Selection of appropriate isolation methods based on different biomarker types is therefore needed for reliable biomarker detection. Our results therefore suggest that a combination of different publicly available miRNA databases should be evaluated in a search for the most promising biomarker candidates associated with AD. However, miRNAs and target genes, highlighted under two different approaches, can be regarded as top novel circulating biomarker candidates in AD. Additionally, the potential of very strong candidates identified in the HMDD as AD circulating biomarkers should be further researched, also in the EVs of body fluids.

\section{Conclusions}

In conclusion, in the present study we prioritized several important experimentally confirmed interactions between miRNAs and target genes implicated in AD. miRNAs hsa-miR-193b, hsa-miR-29c, hsa-miR-613, hsa-miR-206, hsa-miR-128, and hsa-miR-146a represent the most promising circulating AD biomarkers, while miRNAs hsa-miR-375 and hsa-miR-107 could be promising EV-related AD biomarkers. Further studies are needed to evaluate the potential of key identified miRNAs in clinical practice. Elucidating the complex network of AD-related miRNAs and target genes could eventually also enable identification of novel therapeutic targets for AD.

Supplementary Materials: The following are available online at https:/ / www.mdpi.com/article/ 10.3390/jpm11100946/s1, Table S1: List of all AD-associated miRNAs from the HMDD database.

Author Contributions: Conceptualization, D.V. and T.K.; methodology, D.V., K.G. and T.K.; validation, D.V. and K.G.; formal analysis, D.V.; investigation, D.V.; writing—original draft preparation, D.V.; writing-review and editing, K.G., T.K. and V.D.; visualization, D.V.; supervision, K.G., T.K. and V.D.; project administration, K.G. and V.D.; funding acquisition, V.D. All authors have read and agreed to the published version of the manuscript.

Funding: This study was funded by the Javna Agencija za Raziskovalno Dejavnost RS (Eng. Slovenian Research Agency) (ARRS), research grants P1-0170.

Institutional Review Board Statement: Not applicable. 
Informed Consent Statement: Not applicable.

Data Availability Statement: For preparation of the manuscript, the following publicly available databases were used: miRTarBase (https:/ / mirtarbase.cuhk.edu.cn/ miRTarBase/miRTarBase_2019 /php/index.php, accessed on 25 March 2021); the HMDD (https:/ / www.cuilab.cn/hmdd, accessed on 25 March 2021). All the data are presented within the article and in the supplementary material.

Conflicts of Interest: The authors declare no conflict of interest.

\section{References}

1. Förstl, H.; Kurz, A. Clinical features of Alzheimer's disease. Eur. Arch. Psychiatry Clin. Neurosci. 1999, 249, 288-290. [CrossRef]

2. Mayeux, R.; Stern, Y. Epidemiology of Alzheimer Disease. Cold Spring Harb. Perspect. Med. 2012, 2, a006239. [CrossRef] [PubMed]

3. Kocahan, S.; Doğan, Z. Mechanisms of Alzheimer's Disease Pathogenesis and Prevention: The Brain, Neural Pathology, Nmethyl-D-aspartate Receptors, Tau Protein and Other Risk Factors. Clin. Psychopharmacol. Neurosci. 2017, 15, 1-8. [CrossRef] [PubMed]

4. Chaudhury, S.; Brookes, K.J.; Patel, T.; Fallows, A.; Guetta-Baranes, T.; Turton, J.C.; Guerreiro, R.; Bras, J.; Hardy, J.; Francis, P.T.; et al. Alzheimer's disease polygenic risk score as a predictor of conversion from mild-cognitive impairment. Transl. Psychiatry 2019, 9, 1-7. [CrossRef]

5. Jiao, B.; Liu, X.; Zhou, L.; Wang, M.H.; Zhou, Y.; Xiao, T.; Zhang, W.; Sun, R.; Waye, M.M.Y.; Tang, B.; et al. Polygenic Analysis of Late-Onset Alzheimer's Disease from Mainland China. PLoS ONE 2015, 10, e0144898. [CrossRef] [PubMed]

6. Marden, J.R.; Walter, S.; Tchetgen, E.J.T.; Kawachi, I.; Glymour, M.M. Validation of a polygenic risk score for dementia in black and white individuals. Brain Behav. 2014, 4, 687-697. [CrossRef]

7. Lambert, J.C.; Ibrahim-Verbaas, C.A.; Harold, D.; Naj, A.C.; Sims, R.; Bellenguez, C.; DeStafano, A.L.; Bis, J.C.; Beecham, G.W.; Grenier-Boley, B.; et al. Meta-Analysis of 74,046 individuals identifies 11 new susceptibility loci for Alzheimer's disease. Nat. Genet. 2013, 45, 1452-1458. [CrossRef] [PubMed]

8. Jansen, I.E.; Savage, J.E.; Watanabe, K.; Bryois, J.; Williams, D.; Steinberg, S.; Sealock, J.; Karlsson, I.; Hägg, S.; Athanasiu, L.; et al. Genome-wide meta-analysis identifies new loci and functional pathways influencing Alzheimer's disease risk. Nat. Genet. 2019, 51, 404-413. [CrossRef] [PubMed]

9. Kunkle, B.W.; Grenier-Boley, B.; Sims, R.; Bis, J.C.; Damotte, V.; Naj, A.C.; Boland, A.; Vronskaya, M.; Van Der Lee, S.J.; Amlie-Wolf, A.; et al. Genetic meta-analysis of diagnosed Alzheimer's disease identifies new risk loci and implicates A $\beta$, tau, immunity and lipid processing. Nat. Genet. 2019, 51, 414-430. [CrossRef]

10. Takousis, P.; Sadlon, A.; Schulz, J.; Wohlers, I.; Dobricic, V.; Middleton, L.; Lill, C.M.; Perneczky, R.; Bertram, L. Differential expression of microRNAs in Alzheimer's disease brain, blood, and cerebrospinal fluid. Alzheimer's Dement. 2019, 15, 1468-1477. [CrossRef]

11. Silvestro, S.; Bramanti, P.; Mazzon, E. Role of miRNAs in Alzheimer's Disease and Possible Fields of Application. Int. J. Mol. Sci. 2019, 20, 3979. [CrossRef] [PubMed]

12. Lu, M.; Zhang, Q.; Deng, M.; Miao, J.; Guo, Y.; Gao, W.; Cui, Q. An Analysis of Human MicroRNA and Disease Associations. PLOS ONE 2008, 3, e3420. [CrossRef] [PubMed]

13. Huang, H.-Y.; Lin, Y.-C.-D.; Li, J.; Huang, K.-Y.; Shrestha, S.; Hong, H.-C.; Tang, Y.; Chen, Y.-G.; Jin, C.-N.; Yu, Y.; et al. miRTarBase 2020: Updates to the experimentally validated microRNA-target interaction database. Nucleic Acids Res. 2020, 48, D148-D154. [CrossRef] [PubMed]

14. Jack, C.R., Jr.; Bennett, D.A.; Blennow, K.; Carrillo, M.C.; Dunn, B.; Haeberlein, S.B.; Holtzman, D.M.; Jagust, W.; Jessen, F.; Karlawish, J.; et al. NIA-AA Research Framework: Toward a biological definition of Alzheimer's disease. Alzheimer's Dement. 2018, 14, 535-562. [CrossRef]

15. Masters, C.L.; Bateman, R.; Blennow, K.; Rowe, C.C.; Sperling, R.A.; Cummings, J.L. Alzheimer's disease. Nat. Rev. Dis. Prim. 2015, 1, 15056. [CrossRef]

16. Dubois, B.; Hampel, H.; Feldman, H.H.; Scheltens, P.; Aisen, P.; Andrieu, S.; Bakardjian, H.; Benali, H.; Bertram, L.; Blennow, K.; et al. Preclinical Alzheimer's disease: Definition, natural history, and diagnostic criteria. Alzheimer's Dement. J. Alzheimer's Assoc. 2016, 12, 292-323. [CrossRef]

17. Agnello, L.; Piccoli, T.; Vidali, M.; Cuffaro, L.; Sasso, B.L.; Iacolino, G.; Giglio, V.R.; Lupo, F.; Alongi, P.; Bivona, G.; et al. Diagnostic accuracy of cerebrospinal fluid biomarkers measured by chemiluminescent enzyme immunoassay for Alzheimer disease diagnosis. Scand. J. Clin. Lab. Investig. 2020, 80, 313-317. [CrossRef]

18. Mattsson, N.; Andreasson, U.; Zetterberg, H.; Blennow, K. Association of Plasma Neurofilament Light With Neurodegeneration in Patients With Alzheimer Disease. JAMA Neurol. 2017, 74, 557-566. [CrossRef]

19. Lewczuk, P.; Matzen, A.; Blennow, K.; Parnetti, L.; Molinuevo, J.L.; Eusebi, P.; Kornhuber, J.; Morris, J.C.; Fagan, A.M. Cerebrospinal Fluid A 42/40 Corresponds Better than A 42 to Amyloid PET in Alzheimer's Disease the Creative Commons Attrib-ution Non-Commercial License (CC BY-NC 4.0). J. Alzheimer's Dis. 2017, 55, 813-822. [CrossRef]

20. Agnello, L.; Gambino, C.M.; Sasso, B.L.; Bivona, G.; Milano, S.; Ciaccio, A.M.; Piccoli, T.; La Bella, V.; Ciaccio, M. Neurogranin as a Novel Biomarker in Alzheimer's Disease. Lab. Med. 2021, 52, 188-196. [CrossRef] [PubMed] 
21. Agnello, L.; Colletti, T.; Sasso, B.L.; Vidali, M.; Spataro, R.; Gambino, C.M.; Giglio, R.V.; Piccoli, T.; Bivona, G.; La Bella, V.; et al. Tau protein as a diagnostic and prognostic biomarker in amyotrophic lateral sclerosis. Eur. J. Neurol. 2021, 28, 1868-1875. [CrossRef] [PubMed]

22. Vieira, D.; Durães, J.; Baldeiras, I.; Santiago, B.; Duro, D.; Lima, M.; Leitão, M.J.; Tábuas-Pereira, M.; Santana, I. Lower CSF Amyloid-Beta1-42 Predicts a Higher Mortality Rate in Frontotemporal Dementia. Diagnostics 2019, 9, 162. [CrossRef] [PubMed]

23. Virgilio, E.; Vecchio, D.; Crespi, I.; Serino, R.; Cantello, R.; Dianzani, U.; Comi, C. Cerebrospinal Tau levels as a predictor of early disability in multiple sclerosis. Mult. Scler. Relat. Disord. 2021, 56, 103231. [CrossRef] [PubMed]

24. Denk, J.; Boelmans, K.; Siegismund, C.S.; Lassner, D.; Arlt, S.; Jahn, H. MicroRNA Profiling of CSF Reveals Potential Biomarkers to Detect Alzheimer's Disease. PLoS ONE 2015, 10, e0126423. [CrossRef]

25. Graykowski, D.R.; Wang, Y.-Z.; Upadhyay, A.; Savas, J.N. The Dichotomous Role of Extracellular Vesicles in the Central Nervous System. iScience 2020, 23, 101456. [CrossRef]

26. Rajendran, L.; Honsho, M.; Zahn, T.R.; Keller, P.; Geiger, K.D.; Verkade, P.; Simons, K. Alzheimer's disease beta-amyloid peptides are released in association with exosomes. Proc. Natl. Acad. Sci. USA 2006, 103, 11172-11177. [CrossRef]

27. An, K.; Klyubin, I.; Kim, Y.; Jung, J.H.; Mably, A.J.; O’Dowd, S.T.; Lynch, T.; Kanmert, D.; A Lemere, C.; Finan, G.M.; et al. Exosomes neutralize synaptic-plasticity-disrupting activity of $A \beta$ assemblies in vivo. Mol. Brain 2013, 6, 47. [CrossRef]

28. Dinkins, M.B.; Dasgupta, S.; Wang, G.; Zhu, G.; Bieberich, E. Exosome reduction in vivo is associated with lower amyloid plaque load in the 5XFAD mouse model of Alzheimer's disease. Neurobiol. Aging 2014, 35, 1792-1800. [CrossRef]

29. Saman, S.; Kim, W.; Raya, M.; Visnick, Y.; Miro, S.; Saman, S.; Jackson, B.; McKee, A.C.; Alvarez, V.E.; Lee, N.C.; et al. Exosomeassociated Tau Is Secreted in Tauopathy Models and Is Selectively Phosphorylated in Cerebrospinal Fluid in Early Alzheimer Disease. J. Biol. Chem. 2012, 287, 3842-3849. [CrossRef]

30. Badhwar, A.; Haqqani, A.S. Biomarker potential of brain-secreted extracellular vesicles in blood in Alzheimer's disease. Alzheimer's Dementia Diagn. Assess. Dis. Monit. 2020, 12, e12001. [CrossRef]

31. D'Anca, M.; Fenoglio, C.; Serpente, M.; Arosio, B.; Cesari, M.; Scarpini, E.A.; Galimberti, D. Exosome Determinants of Physiological Aging and Age-Related Neurodegenerative Diseases. Front. Aging Neurosci. 2019, 11, 232. [CrossRef]

32. Müller, M.; Kuiperij, H.B.; Versleijen, A.A.; Chiasserini, D.; Farotti, L.; Baschieri, F.; Parnetti, L.; Struyfs, H.; De Roeck, N.; Luyckx, J.; et al. Validation of microRNAs in Cerebrospinal Fluid as Biomarkers for Different Forms of Dementia in a Multicenter Study. J. Alzheimer's Dis. 2016, 52, 1321-1333. [CrossRef]

33. Cao, F.; Liu, Z.; Sun, G. Diagnostic value of miR-193a-3p in Alzheimer's disease and miR-193a-3p attenuates amyloid- $\beta$ induced neurotoxicity by targeting PTEN. Exp. Gerontol. 2020, 130, 110814. [CrossRef] [PubMed]

34. Riancho, J.; Vázquez-Higuera, J.L.; Pozueta, A.; Lage, C.; Kazimierczak, M.; Bravo, M.; Calero, M.; Gonalezález, A.; Rodríguez, E.; Lleó, A.; et al. MicroRNA Profile in Patients with Alzheimer's Disease: Analysis of miR-9-5p and miR-598 in Raw and Exosome Enriched Cerebrospinal Fluid Samples. J. Alzheimer's Dis. 2017, 57, 483-491. [CrossRef] [PubMed]

35. Derkow, K.; Rössling, R.; Schipke, C.; Krüger, C.; Bauer, J.; Fähling, M.; Stroux, A.; Schott, E.; Ruprecht, K.; Peters, O.; et al. Distinct expression of the neurotoxic microRNA family let-7 in the cerebrospinal fluid of patients with Alzheimer's disease. PLoS ONE 2018, 13, e0200602. [CrossRef] [PubMed]

36. Vogrinc, D.; Goričar, K.; Dolžan, V. Genetic Variability in Molecular Pathways Implicated in Alzheimer's Disease: A Comprehensive Review. Front. Aging Neurosci. 2021, 13, 13. [CrossRef] [PubMed]

37. Oliveros, J.C. Venny. An Interactive Tool for Comparing Lists with Venn's Diagrams. Available online: https://bioinfogp.cnb.csic. es/tools/venny/index.html (accessed on 4 May 2021).

38. Tsukamoto, Y.; Nakada, C.; Noguchi, T.; Tanigawa, M.; Nguyen, L.T.; Uchida, T.; Hijiya, N.; Matsuura, K.; Fujioka, T.; Seto, M.; et al. MicroRNA-375 Is Downregulated in Gastric Carcinomas and Regulates Cell Survival by Targeting PDK1 and 14-3-3乙. Cancer Res. 2010, 70, 2339-2349. [CrossRef]

39. Kishore, S.; Jaskiewicz, L.; Burger, L.; Hausser, J.; Khorshid, M.; Zavolan, M. A quantitative analysis of CLIP methods for identifying binding sites of RNA-binding proteins. Nat. Methods 2011, 8, 559-564. [CrossRef]

40. Sarma, N.J.; Tiriveedhi, V.; Crippin, J.S.; Chapman, W.C.; Mohanakumar, T. Hepatitis C Virus-Induced Changes in MicroRNA 107 (miRNA-107) and miRNA-449a Modulate CCL2 by Targeting the Interleukin-6 Receptor Complex in Hepatitis. J. Virol. 2014, 88, 3733-3743. [CrossRef]

41. Liu, C.-G.; Song, J.; Zhang, Y.-Q.; Wang, P.-C. MicroRNA-193b is a regulator of amyloid precursor protein in the blood and cerebrospinal fluid derived exosomal microRNA-193b is a biomarker of Alzheimer's disease. Mol. Med. Rep. 2014, 10, 2395-2400. [CrossRef]

42. Yang, G.; Song, Y.; Zhou, X.; Deng, Y.; Liu, T.; Weng, G.; Yu, D.; Pan, S. MicroRNA-29c targets $\beta$-site amyloid precursor protein-cleaving enzyme 1 and has a neuroprotective role in vitro and in vivo. Mol. Med. Rep. 2015, 12, 3081-3088. [CrossRef]

43. Li, W.; Li, X.; Xin, X.; Kan, P.-C.; Yan, Y. MicroRNA-613 regulates the expression of brain-derived neurotrophic factor in Alzheimer's disease. Biosci. Trends 2016, 10, 372-377. [CrossRef]

44. Yang, G.; Song, Y.; Zhou, X.; Deng, Y.; Liu, T.; Weng, G.; Yu, D.; Pan, S. DNA methyltransferase 3, a target of microRNA-29c, contributes to neuronal proliferation by regulating the expression of brain-derived neurotrophic factor. Mol. Med. Rep. 2015, 12, 1435-1442. [CrossRef] [PubMed] 
45. Xing, H.; Guo, S.; Zhang, Y.; Zheng, Z.; Wang, H. Upregulation of microRNA-206 enhances lipopolysaccharide-induced inflammation and release of amyloid- $\beta$ by targeting insulin-like growth factor 1 in microglia. Mol. Med. Rep. 2016, 14, 1357-1364. [CrossRef] [PubMed]

46. Geng, L.; Zhang, T.; Liu, W.; Chen, Y. Inhibition of miR-128 Abates A $\beta$-Mediated Cytotoxicity by Targeting PPAR- $\gamma$ via NF- $к B$ Inactivation in Primary Mouse Cortical Neurons and Neuro2a Cells. Yonsei Med. J. 2018, 59, 1096-1106. [CrossRef] [PubMed]

47. Zhang, B.; Wang, A.; Xia, C.; Lin, Q.; Chen, C. A single nucleotide polymorphism in primary-microRNA-146a reduces the expression of mature microRNA-146a in patients with Alzheimer's disease and is associated with the pathogenesis of Alzheimer's disease. Mol. Med. Rep. 2015, 12, 4037-4042. [CrossRef]

48. Dehury, B.; Kepp, K.P. Membrane dynamics of $\gamma$-secretase with the anterior pharynx-defective 1B subunit. J. Cell. Biochem. 2021, 122, 69-85. [CrossRef]

49. Acx, H.; Serneels, L.; Radaelli, E.; Muyldermans, S.; Vincke, C.; Pepermans, E.; Müller, U.; Chávez-Gutiérrez, L.; De Strooper, B. Inactivation of $\gamma$-secretases leads to accumulation of substrates and non-Alzheimer neurodegeneration. EMBO Mol. Med. 2017, 9, 1088-1099. [CrossRef]

50. Schwartzentruber, J.; Cooper, S.; Liu, J.Z.; Barrio-Hernandez, I.; Bello, E.; Kumasaka, N.; Young, A.M.H.; Franklin, R.J.M.; Johnson, T.; Estrada, K.; et al. Genome-wide meta-analysis, fine-mapping and integrative prioritization implicate new Alzheimer's disease risk genes. Nat. Genet. 2021, 53, 392-402. [CrossRef]

51. Yanaizu, M.; Washizu, C.; Nukina, N.; Satoh, J.-I.; Kino, Y. CELF2 regulates the species-specific alternative splicing of TREM. Sci. Rep. 2020, 10, 1-13. [CrossRef]

52. Ulland, T.K.; Colonna, M. TREM2-A key player in microglial biology and Alzheimer disease. Nat. Rev. Neurol. 2018, 14, 667-675. [CrossRef] [PubMed]

53. Jonsson, T.; Stefansson, H.; Steinberg, S.; Jonsdottir, I.; Jonsson, P.V.; Snaedal, J.; Bjornsson, S.; Huttenlocher, J.; Levey, A.I.; Lah, J.J.; et al. Variant of TREM2 Associated with the Risk of Alzheimer's Disease. N. Engl. J. Med. 2013, 368, 107-116. [CrossRef] [PubMed]

54. Sims, R.; Van Der Lee, S.J.; Naj, A.C.; Bellenguez, C.; Badarinarayan, N.; Jakobsdottir, J.; Kunkle, B.W.; Boland, A.; Raybould, R.; Bis, J.C.; et al. Rare coding variants in PLCG2, ABI3, and TREM2 implicate microglial-mediated innate immunity in Alzheimer's disease. Nat. Genet. 2017, 49, 1373-1384. [CrossRef] [PubMed]

55. Wijsman, E.M.; Pankratz, N.; Choi, Y.; Rothstein, J.H.; Faber, K.M.; Cheng, R.; Lee, J.H.; Bird, T.D.; Bennett, D.A.; Diaz-Arrastia, R.; et al. Genome-Wide Association of Familial Late-Onset Alzheimer's Disease Replicates BIN1 and CLU and Nominates CUGBP2 in Interaction with APOE. PLoS Genet. 2011, 7, e1001308. [CrossRef] [PubMed]

56. Wang, Q.; Ge, X.; Zhang, J.; Chen, L. Effect of lncRNA WT1-AS regulating WT1 on oxidative stress injury and apoptosis of neurons in Alzheimer's disease via inhibition of the miR-375/SIX4 axis. Aging 2020, 12, 23974-23995. [CrossRef]

57. Pirone, D.M.; Fukuhara, S.; Gutkind, J.S.; Burbelo, P.D. SPECs, Small Binding Proteins for Cdc. J. Biol. Chem. 2000, 275, 22650-22656. [CrossRef]

58. Bamburg, J.R.; Bloom, G.S. Cytoskeletal pathologies of Alzheimer disease. Cell Motil. Cytoskelet. 2009, 66, 635-649. [CrossRef]

59. Rush, T.; Martinez-Hernandez, J.; Dollmeyer, M.; Frandemiche, M.L.; Borel, E.; Boisseau, S.; Jacquier-Sarlin, M.; Buisson, A. Synaptotoxicity in Alzheimer's Disease Involved a Dysregulation of Actin Cytoskeleton Dynamics through Cofilin 1 Phosphorylation. J. Neurosci. 2018, 38, 10349-10361. [CrossRef] [PubMed]

60. Jun, G.; Ibrahim-Verbaas, C.A.; Vronskaya, M.; Lambert, J.C.; Chung, J.; Naj, A.C.; Kunkle, B.W.; Wang, L.S.; Bis, J.C.; Bel-lenguez, C.; et al. A novel Alzheimer disease locus located near the gene encoding tau protein. Mol. Psychiatry 2016, 21, 108-117. [CrossRef] [PubMed]

61. Wood, J.A.; Wood, P.L.; Ryan, R.; Graff-Radford, N.R.; Pilapil, C.; Robitaille, Y.; Quirion, R. Cytokine indices in Alzheimer's temporal cortex: No changes in mature IL-1 $\beta$ or IL-1RA but increases in the associated acute phase proteins IL-6, $\alpha 2$-macroglobulin and C-reactive protein. Brain Res. 1993, 629, 245-252. [CrossRef]

62. Hull, M.; Berger, M.; Volk, B.; Bauer, J. Occurrence of Interleukin-6 in Cortical Plaques of Alzheimer's Disease Patients May Precede Transformation of Diffuse into Neuritic Plaquesa. Ann. N. Y. Acad. Sci. 1996, 777, 205-212. [CrossRef] [PubMed]

63. Islam, O.; Gong, X.; Rose-John, S.; Heese, K. Interleukin-6 and Neural Stem Cells: More Than Gliogenesis. Mol. Biol. Cell 2009, 20, 188-199. [CrossRef]

64. Yang, R.; Duan, J.; Luo, F.; Tao, P.; Hu, C. IL-6, IL-8 and IL-10 polymorphisms may impact predisposition of Alzheimer's disease: A meta-analysis. Acta Neurol. Belg. 2020, 1-8. [CrossRef]

65. Kauwe, J.S.K.; Bailey, M.H.; Ridge, P.G.; Perry, R.; Wadsworth, M.E.; Hoyt, K.L.; Staley, L.A.; Karch, C.; Harari, O.; Cruchaga, C.; et al. Genome-Wide Association Study of CSF Levels of 59 Alzheimer's Disease Candidate Proteins: Significant Associations with Proteins Involved in Amyloid Processing and Inflammation. PLoS Genet. 2014, 10, e1004758. [CrossRef]

66. Haddick, P.C.; Larson, J.L.; Rathore, N.; Bhangale, T.R.; Phung, Q.T.; Srinivasan, K.; Hansen, D.V.; Lill, J.R.; Pericak-Vance, M.A.; Haines, J.; et al. A Common Variant of IL-6R is Associated with Elevated IL-6 Pathway Activity in Alzheimer's Disease Brains. J. Alzheimer's Dis. 2017, 56, 1037-1054. [CrossRef]

67. Chen, W.; Wu, L.; Hu, Y.; Jiang, L.; Liang, N.; Chen, J.; Qin, H.; Tang, N. MicroRNA-107 Ameliorates Damage in a Cell Model of Alzheimer's Disease by Mediating the FGF7/FGFR2/PI3K/Akt Pathway. J. Mol. Neurosci. 2020, 70, 1-9. [CrossRef] [PubMed]

68. Wang, J.; Chen, C.; Zhang, Y. An investigation of microRNA-103 and microRNA-107 as potential blood-based biomarkers for disease risk and progression of Alzheimer's disease. J. Clin. Lab. Anal. 2020, 34, e23006. [CrossRef] [PubMed] 
69. Xie, B.; Zhou, H.; Zhang, R.; Song, M.; Yu, L.; Wang, L.; Liu, Z.; Zhang, Q.; Cui, D.; Wang, X.; et al. Serum miR-206 and miR-132 as Potential Circulating Biomarkers for Mild Cognitive Impairment. J. Alzheimer's Dis. 2015, 45, 721-731. [CrossRef] [PubMed]

70. Yang, T.T.; Liu, C.G.; Gao, S.C.; Zhang, Y.; Wang, P.C. The Serum Exosome Derived MicroRNA-135a, $-193 b$, and -384 Were Potential Alzheimer's Disease Biomarkers. Biomed. Environ. Sci. 2018, 31, 87-96. [PubMed]

71. Montagna, E.; Dorostkar, M.M.; Herms, J. The Role of APP in Structural Spine Plasticity. Front. Mol. Neurosci. 2017, 10, 136. [CrossRef]

72. Haass, C. Take five-BACE and the $\gamma$-secretase quartet conduct Alzheimer's amyloid $\beta$-peptide generation. EMBO J. 2004, 23, 483-488. [CrossRef]

73. Ewers, M.; Cheng, X.; Zhong, Z.; Nural, H.F.; Walsh, C.; Meindl, T.; Teipel, S.J.; Buerger, K.; He, P.; Shen, Y.; et al. Increased CSF-BACE1 Activity Associated with Decreased Hippocampus Volume in Alzheimer's Disease. J. Alzheimer's Dis. 2011, 25, 373-381. [CrossRef] [PubMed]

74. $\quad$ Ewers, M.; Zhong, Z.; Bürger, K.; Wallin, A.; Blennow, K.; Teipel, S.J.; Shen, Y.; Hampel, H. Increased CSF-BACE 1 activity is associated with ApoE- $\varepsilon 4$ genotype in subjects with mild cognitive impairment and Alzheimer's disease. Brain 2008, 131, 1252-1258. [CrossRef]

75. Alexopoulos, P.; Thierjung, N.; Grimmer, T.; Ortner, M.; Economou, P.; Assimakopoulos, K.; Gourzis, P.; Politis, A.; Perneczky, R.; Initiative, T.A.D.N. Cerebrospinal Fluid BACE1 Activity and sA $\beta P P \beta$ as Biomarker Candidates of Alzheimer's Disease. Dement. Geriatr. Cogn. Disord. 2018, 45, 152-161. [CrossRef]

76. Zhong, Z.; Ewers, M.; Teipel, S.; Bürger, K.; Wallin, A.; Blennow, K.; He, P.; McAllister, C.; Hampel, H.; Shen, Y. Levels of $\beta$-Secretase (BACE1) in Cerebrospinal Fluid as a Predictor of Risk in Mild Cognitive Impairment. Arch. Gen. Psychiatry 2007, 64, 718-726. [CrossRef] [PubMed]

77. Wu, G.; Sankaranarayanan, S.; Wong, J.; Tugusheva, K.; Michener, M.S.; Shi, X.; Cook, J.J.; Simon, A.J.; Savage, M.J. Characterization of plasma $\beta$-secretase (BACE1) activity and soluble amyloid precursor proteins as potential biomarkers for Alzheimer's disease. J. Neurosci. Res. 2012, 90, 2247-2258. [CrossRef] [PubMed]

78. Yu, M.; Liu, Y.; Shen, J.; Lv, D.; Zhang, J. Meta-analysis of BACE1 gene rs638405 polymorphism and the risk of Alzheimer's disease in Caucasion and Asian population. Neurosci. Lett. 2016, 616, 189-196. [CrossRef]

79. Maxwell, T.J.; Initiative, A.D.N.; Corcoran, C.; Del-Aguila, J.L.; Budde, J.P.; Deming, Y.; Cruchaga, C.; Goate, A.M.; Kauwe, J.S.K. Genome-wide association study for variants that modulate relationships between cerebrospinal fluid amyloid-beta 42, tau, and p-tau levels. Alzheimer's Res. Ther. 2018, 10, 86. [CrossRef]

80. Saravanaraman, P.; Selvam, M.; Ashok, C.; Srijyothi, L.; Baluchamy, S. De novo methyltransferases: Potential players in diseases and new directions for targeted therapy. Biochimie 2020, 176, 85-102. [CrossRef] [PubMed]

81. Wu, Y.; Xu, J.; Xu, J.; Cheng, J.; Jiao, D.; Zhou, C.; Dai, Y.; Chen, Q. Lower Serum Levels of miR-29c-3p and miR-19b-3p as Biomarkers for Alzheimer's Disease. Tohoku J. Exp. Med. 2017, 242, 129-136. [CrossRef] [PubMed]

82. Cattaneo, A.; Cattane, N.; Begni, V.; Pariante, C.M.; A Riva, M. The human BDNF gene: Peripheral gene expression and protein levels as biomarkers for psychiatric disorders. Transl. Psychiatry 2016, 6, e958. [CrossRef]

83. Hock, C.; Heese, K.; Hulette, C.; Rosenberg, C.; Otten, U. Region-Specific Neurotrophin Imbalances in Alzheimer Disease. Arch. Neurol. 2000, 57, 846-851. [CrossRef] [PubMed]

84. Miranda, M.; Morici, J.F.; Zanoni, M.B.; Bekinschtein, P. Brain-Derived Neurotrophic Factor: A Key Molecule for Memory in the Healthy and the Pathological Brain. Front. Cell. Neurosci. 2019, 13, 363. [CrossRef] [PubMed]

85. Matsushita, S.; Arai, H.; Matsui, T.; Yuzuriha, T.; Urakami, K.; Masaki, T.; Higuchi, S. Brain-derived neurotrophic factor gene polymorphisms and Alzheimer's disease. J. Neural Transm. 2005, 112, 703-771. [CrossRef] [PubMed]

86. Voineskos, A.N.; Lerch, J.P.; Felsky, D.; Shaikh, S.; Rajji, T.K.; Miranda, D.; Lobaugh, N.J.; Mulsant, B.H.; Pollock, B.G.; Kennedy, J.L. The Brain-Derived Neurotrophic Factor Val66Met Polymorphism and Prediction of Neural Risk for Alzheimer Disease. Arch. Gen. Psychiatry 2011, 68, 198-206. [CrossRef] [PubMed]

87. Li, Q.S.; Cai, D. Integrated miRNA-Seq and mRNA-Seq Study to Identify miRNAs Associated With Alzheimer's Disease Using Post-mortem Brain Tissue Samples. Front. Neurosci. 2021, 15, 1-14. [CrossRef]

88. Liang, C.; Zou, T.; Zhang, M.; Fan, W.; Zhang, T.; Jiang, Y.; Cai, Y.; Chen, F.; Chen, X.; Sun, Y.; et al. MicroRNA-146a switches microglial phenotypes to resist the pathological processes and cognitive degradation of Alzheimer's disease. Theranostics 2021, 11, 4103-4121. [CrossRef]

89. Cui, L.; Li, Y.; Ma, G.; Wang, Y.; Cai, Y.; Liu, S.; Chen, Y.; Li, J.; Xie, Y.; Liu, G.; et al. A Functional Polymorphism in the Promoter Region of MicroRNA-146a Is Associated with the Risk of Alzheimer Disease and the Rate of Cognitive Decline in Patients. PLoS ONE 2014, 9, e89019. [CrossRef]

90. Khalilzadeh, B.; Rashidi, M.; Soleimanian, A.; Tajalli, H.; Kanberoglu, G.S.; Baradaran, B.; Rashidi, M.R. Development of a reliable microRNA based electrochemical genosensor for monitoring of miR-146a, as key regulatory agent of neurodegenerative disease. Int. J. Biol. Macromol. 2019, 134, 695-703. [CrossRef]

91. Ansari, A.; Maffioletti, E.; Milanesi, E.; Marizzoni, M.; Frisoni, G.B.; Blin, O.; Richardson, J.C.; Bordet, R.; Forloni, G.; Gennarelli, M.; et al. miR-146a and miR-181a are involved in the progression of mild cognitive impairment to Alzheimer's disease. Neurobiol. Aging 2019, 82, 102-109. [CrossRef]

92. De Oliviera Nascimento, L.; Massari, P.; Wetzler, L.M. The Role of TLR2 in Infection and Immunity. Front. Immunol. 2012,3 , 79. [CrossRef] 
93. Pourbadie, H.G.; Sayyah, M.; Khoshkholgh-Sima, B.; Choopani, S.; Nategh, M.; Motamedi, F.; Shokrgozar, M.A. Early minor stimulation of microglial TLR2 and TLR4 receptors attenuates Alzheimer's disease-related cognitive deficit in rats: Behavioral, molecular, and electrophysiological evidence. Neurobiol. Aging 2018, 70, 203-216. [CrossRef] [PubMed]

94. Lax, N.; Fainstein, N.; Nishri, Y.; Ben-Zvi, A.; Ben-Hur, T. Systemic microbial TLR2 agonists induce neurodegeneration in Alzheimer's disease mice. J. Neuroinflammation 2020, 17, 1-12. [CrossRef]

95. Yu, J.-T.; Mou, S.-M.; Wang, L.-Z.; Mao, C.-X.; Tan, L. Toll-like receptor 2 -196 to -174 del polymorphism influences the susceptibility of Han Chinese people to Alzheimer's disease. J. Neuroinflammation 2011, 8, 136. [CrossRef]

96. Sohrabifar, N.; Gharesouran, J.; Talebi, M.; Ghojazadeh, M.; Ardebili, S.M.M. Association of CLU and TLR2 gene polymorphisms with late-onsetAlzheimer disease in a northwestern Iranian population. Turk. J. Med. Sci. 2015, 45, 1082-1086. [CrossRef] [PubMed]

97. Mukherjee, R.; Jow, L.; Croston, G.E.; Paterniti, J.R.J. Identification, Characterization, and Tissue Distribution of Human Peroxisome Proliferator-activated Receptor (PPAR) Isoforms PPAR $\gamma 2$ versus PPAR $\gamma 1$ and Activation with Retinoid X Receptor Agonists and Antagonists. J. Biol. Chem. 1997, 272, 8071-8076. [CrossRef] [PubMed]

98. Khavinson, V.; Linkova, N.; Kozhevnikova, E.; Trofimova, S. EDR Peptide: Possible Mechanism of Gene Expression and Protein Synthesis Regulation Involved in the Pathogenesis of Alzheimer's Disease. Molecules 2020, 26, 159. [CrossRef]

99. Wang, S.; Guan, L.; Luo, D.; Liu, J.; Lin, H.; Li, X.; Liu, X. Gene- gene interaction between PPARG and APOE gene on late-onset Alzheimer's disease: A case- control study in Chinese han population. J. Nutr. Health Aging 2016, 21, 397-403. [CrossRef]

100. Koivisto, A.M.; Helisalmi, S.; Pihlajamäki, J.; Hiltunen, M.; Koivisto, K.; Moilanen, L.; Kuusisto, J.; Helkala, E.-L.; Hänninen, T.; Kervinen, K.; et al. Association Analysis of Peroxisome Proliferator-Activated Receptor Gamma Polymorphisms and Late Onset Alzheimer's Disease in the Finnish Population. Dement. Geriatr. Cogn. Disord. 2006, 22, 449-453. [CrossRef]

101. Tiribuzi, R.; Crispoltoni, L.; Porcellati, S.; Di Lullo, M.; Florenzano, F.; Pirro, M.; Bagaglia, F.; Kawarai, T.; Zampolini, M.; Orlacchio, A.; et al. miR128 up-regulation correlates with impaired amyloid $\beta(1-42)$ degradation in monocytes from patients with sporadic Alzheimer's disease. Neurobiol. Aging 2014, 35, 345-356. [CrossRef] [PubMed]

102. Liu, Y.; Zhang, Y.; Liu, P.; Bai, H.; Li, X.; Xiao, J.; Yuan, Q.; Geng, S.; Yin, H.; Zhang, H.; et al. MicroRNA-128 knockout inhibits the development of Alzheimer's disease by targeting PPAR $\gamma$ in mouse models. Eur. J. Pharmacol. 2019, 843, 134-144. [CrossRef] [PubMed]

103. Zhang, M.; Han, W.; Xu, Y.; Li, D.; Xue, Q. Serum miR-128 Serves as a Potential Diagnostic Biomarker for Alzheimer's Disease. Neuropsychiatr. Dis. Treat. 2021, 17, 269-275. [CrossRef] [PubMed]

104. Lee, E.-G.; Son, H. Adult hippocampal neurogenesis and related neurotrophic factors. BMB Rep. 2009, 42, 239-244. [CrossRef] [PubMed]

105. Westwood, A.J.; Beiser, A.; DeCarli, C.; Harris, T.B.; Chen, T.C.; He, X.-M.; Roubenoff, R.; Pikula, A.; Au, R.; Braverman, L.E.; et al. Insulin-like growth factor-1 and risk of Alzheimer dementia and brain atrophy. Neurology 2014, 82, 1613-1619. [CrossRef] [PubMed]

106. Rui-Hua, C.; Yong-De, P.; Xiao-Zhen, J.; Chen, J.; Bin, Z. Decreased Levels of Serum IGF-1 and Vitamin D Are Associated With Cognitive Impairment in Patients With Type 2 Diabetes. Am. J. Alzheimer's Dis. Other Dementiasr. 2019, 34, 450-456. [CrossRef]

107. Wang, W.; Yu, J.-T.; Tan, L.; Liu, Q.-Y.; Wang, H.-F.; Ma, X.-Y. Insulin-like growth factor 1 (IGF1) polymorphism is associated with Alzheimer's disease in Han Chinese. Neurosci. Lett. 2012, 531, 20-23. [CrossRef] [PubMed]

108. Xie, B.; Liu, Z.; Jiang, L.; Liu, W.; Song, M.; Zhang, Q.; Zhang, R.; Cui, D.; Wang, X.; Xu, S. Increased Serum miR-206 Level Predicts Conversion from Amnestic Mild Cognitive Impairment to Alzheimer's Disease: A 5-Year Follow-up Study. J. Alzheimer's Dis. 2016, 55, 509-520. [CrossRef]

109. Moon, J.; Lee, S.-T.; Kong, I.G.; Byun, J.-I.; Sunwoo, J.-S.; Shin, J.-W.; Shim, J.-Y.; Park, J.-H.; Jeon, D.; Jung, K.-H.; et al. Early diagnosis of Alzheimer's disease from elevated olfactory mucosal miR-206 level. Sci. Rep. 2016, 6, 20364. [CrossRef]

110. Wang, C.-N.; Wang, Y.-J.; Wang, H.; Song, L.; Chen, Y.; Wang, J.-L.; Ye, Y.; Jiang, B. The Anti-dementia Effects of Donepezil Involve miR-206-3p in the Hippocampus and Cortex. Biol. Pharm. Bull. 2017, 40, 465-472. [CrossRef]

111. Dangla-Valls, A.; Molinuevo, J.L.; Altirriba, J.; Sanchez-Valle, R.; Alcolea, D.; Fortea, J.; Rami, L.; Balasa, M.; Muñoz-García, C.; Ezquerra, M.; et al. CSF microRNA Profiling in Alzheimer's Disease: A Screening and Validation Study. Mol. Neurobiol. 2016, 54, 6647-6654. [CrossRef] [PubMed]

112. Cosín-Tomàs, M.; Antonell, A.; Lladó, A.; Alcolea, D.; Fortea, J.; Ezquerra, M.; Lleó, A.; Martí, M.J.; Pallàs, M.; Sanchez-Valle, R.; et al. Plasma miR-34a-5p and miR-545-3p as Early Biomarkers of Alzheimer's Disease: Potential and Limitations. Mol. Neurobiol. 2017, 54, 5550-5562. [CrossRef]

113. Müller, M.; Jäkel, L.; Bruinsma, I.B.; Claassen, J.A.; Kuiperij, B.; Verbeek, M.M. MicroRNA-29a Is a Candidate Biomarker for Alzheimer's Disease in Cell-Free Cerebrospinal Fluid. Mol. Neurobiol. 2016, 53, 2894-2899. [CrossRef] [PubMed]

114. Leidinger, P.; Backes, C.; Deutscher, S.; Schmitt, K.; Mueller, S.C.; Frese, K.; Haas, J.; Ruprecht, K.; Paul, F.; Stähler, C.; et al. A blood based 12-miRNA signature of Alzheimer disease patients. Genome Biol. 2013, 14, R78. [CrossRef]

115. Denk, J.; Oberhauser, F.; Kornhuber, J.; Wiltfang, J.; Fassbender, K.; Schroeter, M.L.; Volk, A.E.; Diehl-Schmid, J.; Prudlo, J.; Danek, A.; et al. Specific serum and CSF microRNA profiles distinguish sporadic behavioural variant of frontotemporal de-mentia compared with Alzheimer patients and cognitively healthy controls. PLoS ONE 2018, 13, e0197329. [CrossRef] [PubMed] 
116. Manzine, P.R.; Pelucchi, S.; Horst, M.A.; Vale, F.A.; Pavarini, S.C.; Audano, M.; Mitro, N.; Di Luca, M.; Marcello, E.; Cominetti, M.R. microRNA 221 Targets ADAM10 mRNA and is Downregulated in Alzheimer's Disease. J. Alzheimer's Dis. 2017, 61, 113-123. [CrossRef]

117. Gui, Y.; Liu, H.; Zhang, L.; Lv, W.; Hu, X. Altered microRNA profiles in cerebrospinal fluid exosome in Parkinson disease and Alzheimer disease. Oncotarget 2015, 6, 37043-37053. [CrossRef] [PubMed]

118. Yang, Q.; Zhao, Q.; Yin, Y. miR-133b is a potential diagnostic biomarker for Alzheimer's disease and has a neuroprotective role. Exp. Ther. Med. 2019, 18, 2711-2718. [CrossRef] [PubMed] 